\title{
Management of Jibing Springs Based on Community in Prawoto Village, Sukolilo District, Pati Regency
}

\author{
Lalik Fatmawati ${ }^{1}$, Moh. Gamal Rindarjono ${ }^{2}$, dan $\mathrm{Ahmad}^{3}$ \\ \{lalikfatmawati@yahoo.co.id $\left.{ }^{1}\right\}$ \\ Geography Education, Universitas Sebelas Maret ${ }^{1,2,3}$
}

\begin{abstract}
Springs or often known as sendang become the main source to meet the needs of clean water for the community in Prawoto Village, Sukolilo District, Pati Regency. To meet the needs of clean water originating from springs, management management is needed for the distribution of the water. The purpose of this study was to find out the management of Jibing spring in Prawoto Village, Sukolilo District, Pati Regency. The method used was a case study. Data collection techniques with interviews. Sampling was done by Purposive Sampling. The results showed that the management of Sendang Jibing which includes the distribution of water from springs is carried out by means of groups and individuals. In addition, Sendang Jibing was also used as a place of recreation which had an impact on improving the economy of the surrounding community.
\end{abstract}

Keywords: economy, management, springs, and water needs.

\section{Introduction}

Water is a basic need that must be fulfilled in people's lives, both rural communities and urban communities. Not only humans, animals and plants also need water for their survival. Water that can be used by the community to fulfill their needs can come from various sources, from surface water or groundwater.

Prawoto Village is one of the villages in the Sukolilo District of Pati Regency, which is geologically included in the Sukolilo karst area [1]. Where, the area shows exokarst and endokasrt forms, one of which forms endokarst includes springs [2]. Springs are ground water that comes out by itself to the surface of the ground. Springs originating from deep soil are almost unaffected by season and the quality / quantity is the same as in deep water [3].

There are nine springs in Prawoto village which are the main sources of water that are highly relied upon to meet the needs of community clean water with an average discharge of 10 liters/second (Settlement Sanitation Development Program (PPSP) Pati, 2012). One of them is Sendang Jibing.

Water needs in an area are sometimes not comparable with the availability of water in the area. This can be caused by a high population which causes high water demand, while limited water sources and uneven distribution of water sources. As written by [4] "The growing population and continuous pressure on the available water resources and this has been produced in reduction of per capita water availability".

Community water needs generally include water requirements for domestic, water requirements for agriculture, water requirements for livestock, and water requirements for home industries. Domestic water needs according to [5] are used for all household needs, including 
cooking, drinking, bathing, sanitary ware, and so on. Water requirements for agriculture are used for irrigating rice fields, fields and moorings. Water requirements for livestock are used to fulfill livestock and fisheries needs. Industrial water needs are used to fulfill the processing industry and home industries. For this reason, it is necessary to have a management of springs so that the distribution of water from the spring can be evenly distributed and facilitate the economic activities of the community.

\section{$2 \quad$ Method}

The method used is a case study. The technique of collecting data by interview and observation. The population is the entire population of users of Jibing spring, while sampling is done by Purposive Sampling technique, which consists of, the community using the spring, the manager of the distribution of springs, and traders around the spring of Jibing. The data analysis technique uses qualitative descriptive.

\section{$3 \quad$ Results and Discussion}

\subsection{Water Needs from Sendang Jibing}

Prawoto Village consists of six (6) Hamlets, namely: Plosokerep Hamlet, Sawahan Hamlet, Domasan Hamlet, Karangtandan Hamlet, Sewunegaran Hamlet, and Perangan Hamlet. Sendang Jibing with a debit of around 30 liters / second is located on Dk. Sewunegaran RT.05 / RW.05.

According to [6] concerning Technical Guidelines for Implementing Government Tasks in the Management of Groundwater, that the Allocation of the use of underground water for drinking water needs is a top priority above all other needs. The priority order for underground water allocation is as follows drinking water, water for households, water for livestock and simple farming, water for industry, water for irrigation, water for mining, water for urban businesses, and water for other purposes.

Springs as a source of water supply, can be directly used by people in the place where the spring appears, usually by people who live near the source of the spring, but there are also those that are first accommodated and then distributed or distributed to the wider community to make it easier to use it .

Table 1. Domestic Clean Water Needs from Sendang Jibing

\begin{tabular}{cccccr}
\hline No. & Hamlet & $\begin{array}{c}\text { User } \\
\text { (person) }\end{array}$ & $\begin{array}{c}\text { Average water } \\
\text { use value }\end{array}$ & Unit & $\begin{array}{c}\text { Total water requirements } \\
\text { (liters / day) }\end{array}$ \\
\hline 1 & Karangtandan & 1,076 & 193 & liter/person/day & 207,668 \\
2 & Sewunegaran & 1,506 & 193 & liter/person/day & 290,658 \\
& Total & 2,582 & & & 498,326 \\
\hline
\end{tabular}

Sendang Jibing is one of the spring in Prawoto Village, Sukolilo Subdistrict, Pati Regency, which is widely used to meet the needs of clean water for the community, especially in Karangtandan and Sewunegaran hamlets. Both domestic and non-domestic needs. 
For domestic needs, the community uses it to cook, drink, bathe, wash, worship (ablution), and others.

Based on Table 1. The number of clean water users from Sendang Jibing is 2,582 people with a total water requirement for domestic needs of around 498,326 liters / day. The number was obtained from Karangtandan hamlet of 1,076 users with total clean water needs of around 207,668 liters / day and Sewunegaran hamlets with 1,506 users with total clean water needs of around 290,658 liters / day.

Whereas non-domestic needs are used for public facilities, such as health centers, mosques, prayer rooms, schools and industries.

Table 2. Need for Non-Domestic Clean Water from Sendang Jibing

\begin{tabular}{|c|c|c|c|c|c|}
\hline No. & Sector & Person/unit & Value & Unit & Total \\
\hline 1 & School & 1,921 & 5 & liter/student/day & 9,605 \\
\hline 2 & Puskesmas & 1 & 1,200 & liter/unit/ day & 1,200 \\
\hline 3 & Mosque & 1 & 3,000 & liter/unit/ day & 3,000 \\
\hline 4 & Musholla & 8 & 2,000 & liter/unit/ day & 16,000 \\
\hline 5 & Market & 0 & 12,000 & liter/hectar/ day & 0 \\
\hline 6 & Industry & 17 & 10 & liter/ day & 170 \\
\hline \multicolumn{5}{|c|}{ Total } & 29,975 \\
\hline
\end{tabular}

Based on Table 2. The need for non-domestic clean water using water from Sendnag Jibing is a school consisting of TK PGRI 15 Sukolilo, SDN 01 Prawoto, SDN 02 Prawoto, SMP PGRI 15 Sukolilo, MTs Sunan Prawoto, and MA Sunan Prawoto with total students and education staff as many as 1,921 people. To fulfill the highest demand for clean water, there is the Musholla sector, with a total clean water requirement of around 16,000 liters / day.

Table 3. Comparison of Availability and Need for Clean Water from Sendang Jibing

\begin{tabular}{crrrrrrr}
\hline \multirow{2}{*}{$\begin{array}{c}\text { Source of } \\
\text { Springs }\end{array}$} & \multicolumn{2}{c}{ Springs discharge } & \multicolumn{3}{c}{ Clean Water Needs } \\
liter/second & liter/day & Domestic & $\begin{array}{l}\text { Non- } \\
\text { Domestic }\end{array}$ & $\begin{array}{l}\text { Total } \\
\text { (liter/day) }\end{array}$ & Surplus & Defisit \\
\hline Jibing & 30 & $2,592,000$ & 498,326 & 29,975 & 528,301 & $2,063,699$ & 0 \\
\hline
\end{tabular}

Based on Table 3. Comparison of water availability and clean water needs have a surplus of 2,063,699 liters / day, which means that there are excess water every day as many as 2,063,699 liters. The excess water is flowed through small rivers and can be used for other nondomestic water needs that do not require using clean water. For example for drinking livestock, watering plants around the house, irrigation, and others.

From the results of these calculations it turns out that it is in accordance with the results of interviews that the community has never lacked clean water, both in the rainy season and in the dry season. 


\subsection{Management of Sendang Jibing}

The distribution of water from Sendang is managed by the surrounding community in groups and individually. Each group installs a pipe as a primary outlet with a pipe size of 4 or 2 inches directly in the spring. Then distributed to secondary outlets in the form of kucu, from the grandchildren, then distributed to homes by using a hose with a gravity system. So only the people whose homes are located lower than the location of springs that can collect water in groups, that is, some people who live in the hamlets of Karangtandan and Sewunegaran. In addition, there are also some people who live near the spring to collect water from their eyes individually using a water pump, the reason is that it saves more money. For operational costs that are distributed by different communities depending on each group, ranging from Rp. 3,000 to Rp. 5,000 per month.

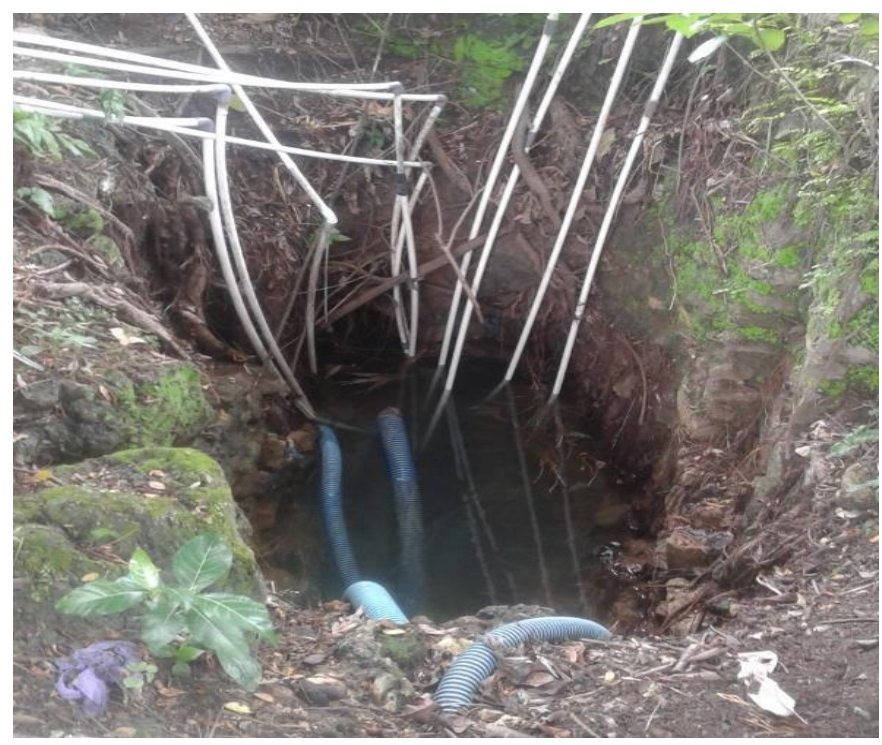

Fig. 1. Water withdrawal from Sendang Jibing

In addition, the surrounding community also uses water directly from the spring, both bathing, washing, and washing vehicles by making special places. Formerly, Sendang Jibing was a Tamansari in the Dutch era which until now is still used and developed as a water tourism spot. By developing it into a water tourism place, this spring has a positive impact on the surrounding community, especially the improvement of the community's economy. Especially after the improvements to the pond that was used for recreational water, the spring is increasingly crowded by visitors and many food stalls are selling food. In addition to stalls there are also rental tires for swimming by the surrounding community.

Even though it is used as a place of recreation, there is no charge when you want to tour this spring. This makes the jibing visitors more crowded and profitable for traders and tire rentals, especially when there are events in the village, such as Haul Sunan Prawoto, 17th August, Haul Mbah Tabek Merto Prawoto, and other events. 


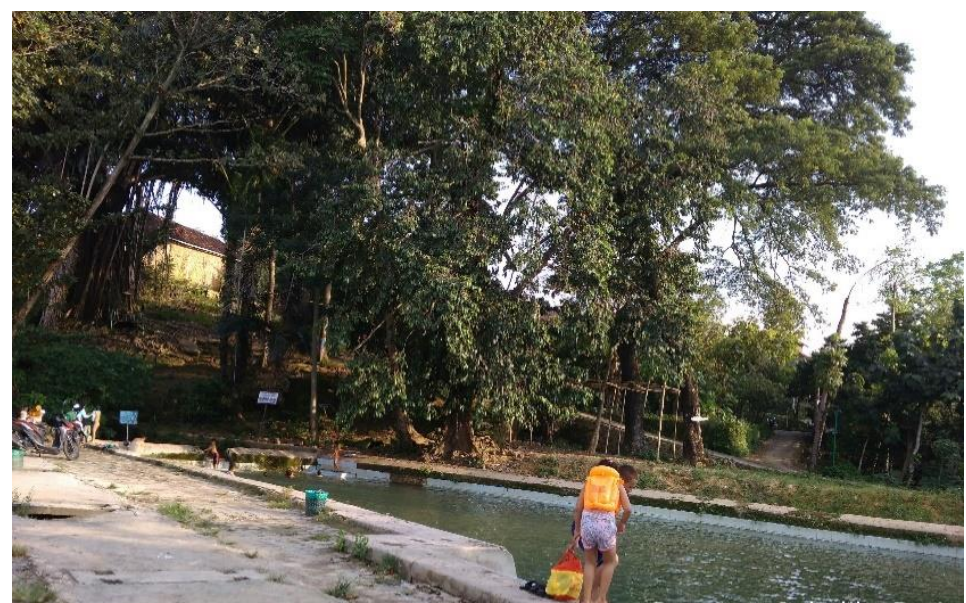

Fig. 2. Sendang Jibing for Water Tourism

\section{Conclusion}

The Jibing spring is the main source for meeting the needs of clean water for the people of Karangtandan and Sewunegaran hamlets, both for domestic and non-domestic water needs. To meet the water needs of these springs, management is carried out by distributing springs to residents' houses and to public facilities in the Karantandan and Sewunegaran hamlets. Besides that, Sendang Jibing is also used for recretion sites (water tourism) which contribute to improving the economy of the surrounding community.

Acknowledgement. The author would like to thank the Head of Prawoto Village, Manager of Sendang Jibing, Prawoto village community, Magister Program of Geography Education FKIP UNS Surakarta and all those who helped in completing this research.

\section{References}

[1] Keputusaan Mentri Energi dan Sumber Daya Mineral. Nomor 2641 K/40/MEM/2014 tentang Penetapan Kawasan Bentang Alam Karst Sukolilo.

[2] Peraturan Mentri Energi dan Sumber Daya Mineral. Nomor 17 Tahun 2012 tentang Penetapan Kawasan Bentang Alam Karst Sukolilo.

[3] T Sutrisno. (2002). Teknologi Penyediaan Air Bersih. Jakarta : Rineka Cipta.

[4] D A Ondigo, A. M Kavoo, \& J Kebwaro. (2018). Water Resources and Management under Increasing Urban Demography: A Kenyan Perspective-A Review. Journal of Water Resource and Protection, 10, 919-938.

[5] Kodoatie, Robert J. \& Widiarto. (2016). Menjaga Kedaulatan Air. Yogyakarta : Penerbit Andi.

[6] Keputusaan Mentri Energi dan Sumber Daya Mineral. Nomor 1541 K/10/MEM/2000 tentang Pedoman Teknis Penyelenggaraan Tugas Pemerintah di Bidang Pengelolaan Air Bawah Tanah. 